\title{
Associação da ocorrência do ectima contagioso (ORF vírus) em ovinos com os cuidadores desses animais
}

\author{
[Occurrence of the Association contagious ecthyma (ORF virus) in sheep with \\ these animals' caregivers] \\ B.L.S. Ferreira ${ }^{1}$, D.T. Silva ${ }^{1}$, E.M. Pituco ${ }^{2}$, C.P. Ribeiro ${ }^{2}$, L.H. Okuda ${ }^{2}$, C. Victoria ${ }^{3}$, \\ J.C.F. Pantoja ${ }^{3}$, J.R. Modolo \\ ${ }^{1}$ Aluno de pós-graduação - Universidade Estadual Paulista - Botucatu, SP \\ ${ }^{2}$ Instituto Biológico de São Paulo - São Paulo, SP \\ ${ }^{3}$ Universidade Estadual Paulista - Botucatu, SP
}

\begin{abstract}
RESUMO
A enfermidade ectima contagioso está difundida em todo o estado de São Paulo. Foram amostrados 42 $(8,64 \%)$ cuidadores de animais e $444(91,36 \%)$ ovinos $(n=486)$. A prevalência de reagentes para vírusneutralização foi de 67\% (IC95\%=62-71\%) nos ovinos, e em seus cuidadores de 76\% (IC95\%=63-89\%), sendo $\mathrm{P}=0,22$, ou seja, não houve diferença estatística significativa entre as espécies. A distribuição dos títulos teve diferença estatística significativa entre as espécies, com $P=0,0048$. As variações de titulação foram de 0,6 a 2,1 tanto nos ovinos quanto nos seus cuidadores. Dentre os 42 cuidadores de ovinos participantes do estudo, 32 apresentaram títulos de anticorpos expressos por $\log 10$ acima de 0,6.
\end{abstract}

Palavras-chave: ORF vírus, vírus-neutralização, animais, humanos.

\begin{abstract}
These diseases are all widespread in the State of São Paulo. 42 (8.64\%) animal caregivers and 444 $(91.36 \%)$ sheep $(n=486)$ were sampled. The reagents Prevalence paragraph virus neutralization was $67 \%$ (95\% CI $=62-71 \%$ ) in sheep and 76\% (95\% CI =63-89\%) for caregivers, with $P=0.22$ not being a statistically significant difference between the species. One of the distribution titles had significant difference between statistics as species with $P=0.0048$. The titration variations were 0.6 to 2.1 , both in sheep and their caregivers. Among the 42 sheep caregivers participating in the study, 32 had antibody securities denominated in $\log _{10}$ above 0.6.
\end{abstract}

Keywords: ORF virus, virus neutralization, animals, humans

\section{INTRODUÇÃO}

Nos ovinos, ORF vírus merece destaque (Barros, 2007; Radostitis et al., 2012) por ser uma enfermidade zoonótica de caráter ocupacional, acometendo mais comumente os cuidadores dos ovinos (Nourani e Maleki, 2006). As infecções acidentais, além de poderem acometer os humanos (Kuroda et al., 1999), também podem infectar bovinos, caninos (Barros, 2007), felinos e animais silvestres (Al-Salam et al., 2008).

Recebido em 8 de julho de 2015

Aceito em 4 de abril de 2016

*Autor para correspondência (corresponding author)

E-mail: jrmodolo@fmvz.unesp.br
O ORF vírus está mundialmente distribuído (Radostitis et al., 2012). O primeiro caso em ovelhas foi descrito por Steeb em 1787, e em humanos foi registrado por Newson e Cross em 1934 e citado Barravieira (2005).

É uma enfermidade viral, que causa lesões crostosas e proliferativas na pele e nas junções mucocutâneas (Haig e Mercer, 1998; Pugh, 2005). A doença provoca atraso de desenvolvimento e graus variados de dor, além de perdas econômicas. Embora comum em cordeiros com três a seis meses de idade, os 
animais de 10 a 12 dias de idade (Radostitis et al., 2012) são mais vulneráveis, ocasionando lesões inflamatórias proliferativas ao redor da boca e das narinas (Haig, 2006), as quais são progressivas e debilitantes, reduzindo a capacidade de alimentação dos animais (Haig, 2006; Fleming e Mercer, 2007). Quando a infecção é introduzida pela primeira vez no rebanho, os animais adultos também podem se infectar (Barros, 2007).

Os surtos em ovinos ocorrem a qualquer tempo, porém são mais comuns em condições secas nos animais de pasto (Radostitis et al., 2012). A disseminação é muito rápida e ocorre pelo contato com outros animais acometidos ou por fômites, resultando em um surto (Pugh, 2005; Radostitis, 2012). O vírus penetra na pele lesada, que evolui para pápulas, vesículas, pústulas e crostas, diminuindo a lucratividade do produtor (Robinson e Balassu, 1981).

Em humanos, a infecção pelo ORF vírus é similar em aparência e proporciona fatores de risco para infecções potencialmente fatais, como antraz cutâneo, tularemia, inoculação primária de tuberculose, cancro sifilítico, esporotricose, granuloma piogênico, neoplasia (Geernick et al., 2001); dessa forma, tanto a infecção pelo ORF vírus como pelo antraz são adquiridas naturalmente por humanos que têm exposição junto aos ovinos e cabras (Uzel et al., 2005). Assim como nos animais, não há tratamento específico em humanos para essa enfermidade (Radostitis et al., 2012).

Este estudo objetivou analisar a associação da resposta imune humoral ao ORF vírus entre os animais, e destes com seus cuidadores, por meio do teste de vírus-neutralização (VN).

\section{MATERIAL E MÉTODOS}

Foram selecionadas 20 propriedades, distribuídas por todo o estado de São Paulo, com relatos de positividade da doença no rebanho. A seleção dessas propriedades foi realizada por meio de palestras com produtores, telefonemas, participação em dias de campo e exposições agropecuárias, ajuda de órgãos oficiais, como a Associação Paulista de Criadores de Ovinos, a Coordenadoria de Assistência Técnica Integral/Secretaria de Agricultura e
Abastecimento do Estado de São Paulo (CATI) e a Casa da Agricultura.

Os animais foram selecionados de acordo com o relato do cuidador sobre o aparecimento anterior de sinais clínicos e/ou a percepção desses sinais durante a visita às propriedades e aos locais com relatos anteriores de surtos. Porém, se, no momento da visita, não havia animais clinicamente doentes, foram escolhidos de forma aleatória animais que já estiveram doentes e/ou ficaram em contato direto (mesmo lote) com os doentes. Não foram considerados, em ambos os casos, idade e sexo no processo de amostragem. Em cada propriedade, foi coletado material biológico de pelo menos 20 animais.

Foram coletados $5 \mathrm{~mL}$ de sangue, por venopunção jugular, diretamente em frascos tipo Vaccutainer®. Posteriormente, estes foram armazenados em caixas isotérmicas com gelo para serem transportados. No laboratório, o sangue foi centrifugado, e o soro acondicionado em tubos tipo Eppendorf® devidamente identificados, congelados a $-20^{\circ} \mathrm{C}$ e transportados ao Laboratório de Viroses de Bovídeos, no Instituto Biológico de São Paulo (LVB/IB), para a realização das análises.

Em todas as propriedades, foi coletado sangue das pessoas que cuidavam desses animais, não se levando em consideração a idade e o sexo deles. $\mathrm{O}$ procedimento de coleta do material nos cuidadores foi realizado por uma auxiliar de enfermagem habilitada e credenciada junto ao Conselho Regional de Enfermagem (Coren), sempre acompanhada da médica veterinária responsável pelo projeto. As amostras humanas também foram encaminhadas e processadas no Laboratório de Viroses de Bovídeos, no Instituto Biológico de São Paulo.

Todas as propriedades assinaram dois Termos de Consentimento Livre e Esclarecido, um identificava o número de animais utilizados, o outro era destinado aos cuidadores que contribuíram com a pesquisa. Nos dois constavam dados específicos dos indivíduos, que aceitavam participar do estudo e autorizavam a coleta do sangue.

Primeiramente, foi realizado o cultivo celular, utilizando-se a linhagem VERO CCL 80 (rim de macaco-verde-africano), proveniente da 
“American Type Culture Collection" (ATCC) Manassas, EUA, para titulação viral e testes de vírus-neutralização. $O$ estoque de células foi mantido em nitrogênio líquido no $\mathrm{LVB} / \mathrm{IB}$, as quas foram descongeladas periodicamente para uso, no máximo, de 20 passagens após o descongelamento. As células foram cultivadas em meio essencial mínimo (MEM - Cultilab, Campinas, Brasil), acrescido de $0,2 \%$ de bicarbonato de sódio (Merck, Darmstadt, Alemanha), tamponado com $25 \mathrm{mM}$ de ácido 4(2-hidroxietil)-1-piperazineetanossulfônico (HEPES - Biosolve, Westford, EUA) e suplementado com 5\% de soro fetal bovino livre (SFB - Cultilab, Campinas, Brasil). Para a manutenção, as células foram cultivadas em frascos de poliestireno, com $150 \mathrm{~cm}^{2}$ de área (Corning, New York, EUA) e mantidas em estufa em temperatura de $37^{\circ} \mathrm{C}$. Os subcultivos foram realizados a cada 72 horas, utilizando-se uma solução tripsina-versene (Sigma-Aldrich, Steinheim, Alemanha) para a desagregação das células. A concentração utilizada foi de 2 x 105 células/mL, e a contagem feita em câmara de Neubauer (Optik Labor, Friedrichshofen, Alemanha). O vírus utilizado foi o ORF vírus (ORF Vírus): origem ATCC, adquirido pelo LVB/IB em 30/08/2007 (ATCC VR - 1548).

Após essa etapa, iniciou-se a replicação viral em garrafas com 24 horas de monocamada celular pré-formada. As células foram infectadas com títulos (104,7 DICC50/mL - doses infectantes em cultivo de células $50 \%$ por $\mathrm{mL}$ ), acrescidas de $55 \mathrm{~mL}$ de MEM com 5\% de SFB e $1 \%$ de antibióticos: penicilina $\mathrm{G}$ potássica 11.200UI $/ \mathrm{mL}$; estreptomicina $\quad 0,01 \mathrm{~g} / \mathrm{ml}$; gentamicina $0,01 \mathrm{~g} / \mathrm{mL}$; L-glutamina $0,029 \mathrm{~g} / \mathrm{mL}$ e anfotericina B $0,5 \mathrm{mg} / \mathrm{mL}$ (Cultilab, Campinas, Brasil) e permaneceram a $37^{\circ} \mathrm{C}$. O cultivo foi observado diariamente, e após $90 \%$ de destruição da monocamada celular, a suspensão viral foi recolhida, centrifugada a $600 \mathrm{x}$ g, por 15 minutos, a $+4^{\circ} \mathrm{C}$ (IEC, International Centrifuge, modelo PR-2, Needham, EUA), e as alíquotas foram feitas em tubos de criogenia (TPP, Techno Plastic Products AG, Suiça), que foram armazenadas em nitrogênio líquido $-196^{\circ} \mathrm{C}$ até o momento do uso.

O teste de vírus-neutralização (VN) foi utilizado para quantificar os anticorpos neutralizantes presentes no soro dos ovinos e humanos estudados frente ao ORF vírus. Foram utilizadas placas de microtitulação com 96 cavidades, de fundo chato. A coluna um da placa teste foi destinada para o controle de células, a coluna dois para controle da toxicidade de cada soro, e nas colunas três até 12 , as amostras foram diluídas em série, na base logarítmica 2, a partir da diluição $1: 2$ até $1: 1.024$, utilizando-se meio MEM. Para validação da prova, foi incluído soro padrão negativo, fraco positivo e positivo com títulos de anticorpos. Feita a diluição das amostras, foram adicionados à placa 1000DICC50/mL do vírus, exceto no controle de células e de soro. Na placa controle de doses, as colunas um a 10 receberam o controle de DICC $50 / \mathrm{mL}(1,95$ a $1000 \mathrm{DICT} 50 / \mathrm{mL})$, e as colunas 11 e 12 serviram como controle negativo, recebendo somente meio MEM. Para o controle da titulação viral, a placa recebeu diluições seriadas na base 10 do vírus (10-2 a 108), e as colunas 11 e 12 serviram como controle negativo, recebendo somente meio MEM. As placas foram incubadas por uma hora em estufa a $37^{\circ} \mathrm{C}$ com $5 \%$ de $\mathrm{CO} 2$; após esse período, receberam $50 \mu \mathrm{L}$ de suspensão de células VERO na concentração de $3 \times 105$ células/mL, em cada cavidade. A infectividade foi indicada pelo efeito citopático visível na monocamada celular em placas, em microscópio invertido, após cinco a sete dias de incubação a $+37^{\circ} \mathrm{C}$ e $5 \%$ de $\mathrm{CO} 2$. O título de anticorpos foi expresso como a maior diluição do soro que inibiu completamente a infectividade em ambas as cavidades de cada diluição, sendo a menor diluição detectada pela prova 1:2, cujo título será calculado e expresso em $\log 10$; meio MEM foi utilizado como diluente. Foram consideradas reagentes as amostras com título igual ou superior a 0,6 $\log 10$. O teste foi validado quando as células das cavidades destinadas ao controle de células permaneceram intactas; as células da cavidade para controle de toxidez dos soros também permaneceram inalteradas, ou seja, não apresentaram efeito tóxico, e os soros controle negativo, fraco positivo e positivo apresentaram os resultados esperados. Com relação ao controle de doses, a prova foi validada quando a dose infectante ficou entre 300 e 3000 DICC $50 / \mathrm{mL}$ e se na retitulação viral o título obtido apresentou variação de apenas $\pm 03 \log 10$ quando comparado com o título da solução estoque, calculado conforme método de Reed e Muench (1938). As amostras de soros controle foram selecionadas pelo LVB/IB, com base nas amostras de animais positivos e negativos, recebidas na rotina de 
análises nos últimos 30 anos. Dentre estas, utilizaram-se soros pareados de animais que apresentaram lesões causadas por ectima contagioso, com diagnóstico confirmado por PCR. As amostras foram validadas como padrão, após, no mínimo, três repetições por soro na vírus-neutralização, em, no mínimo, quadriplicata, e em três dias alternados, comprovando a repetibilidade e a reprodutibilidade do resultado.

Para a titulação viral, foram tituladas as estirpes em placas de microtitulação de poliestireno, de fundo chato, com 96 cavidades (Corning, New York, EUA), em diluições seriadas na base 10 (10-1 a 10-9), sendo diluídas em meio MEM com $1 \%$ de antibióticos, 100L por cavidade, em oito repetições. As duas últimas colunas foram utilizadas como controle de células, não recebendo inóculo viral. Imediatamente em seguida, 50L de uma suspensão de 3 x 105 células $/ \mathrm{mL}$, preparada em meio MEM contendo $5 \%$ de SFB, foram adicionados em cada uma das cavidades. As placas foram incubadas em estufa $37^{\circ} \mathrm{C}$ com 5\% de $\mathrm{CO} 2$ (Thermo Electron Corporation, Waltham, EUA) por cinco a sete dias. A leitura foi realizada em microscópio invertido. O título viral foi calculado utilizandose o método de Reed e Muench (1938).

Inicialmente, distribuições de frequência das variáveis categóricas foram produzidas para caracterizar a amostra do estudo; dessa forma, as prevalências de positividade sorológica foram estimadas com respectivos intervalos de confiança de $95 \%$ na população estudada de ovinos e seus cuidadores. A distribuição de frequência dos títulos dos ovinos e de seus cuidadores foi produzida para descrever a intensidade das reações sorológicas. O teste de qui-quadrado e o teste de Fisher foram utilizados para: 1) comparar a prevalência de soropositividade entre ovinos e seus cuidadores; 2) comparar a distribuição dos títulos entre ovinos e seus cuidadores. A análise estatística foi realizada com SAS (SAS Institute, 2011) em nível de significância de 0,05.

O presente trabalho foi aprovado pela Comissão de Ética no Uso de Animais (Ceua) da Faculdade de Medicina Veterinária e Zootecnia (FMVZ), Unesp, Campus Botucatu, sob o protocolo n. ${ }^{\circ}$ 37/2013-CEUA, bem como pelo Conselho Nacional de Controle de Experimentação Animal (Concea), sob o protocolo (Ceua) n. ${ }^{\circ}$ 1033-2013 e pelo Ministério da Saúde, sob o CAAE n. ${ }^{\circ} 19071013.7 .0000 .5411$.

\section{RESULTADOS E DISCUSSÃO}

A Fig. 1 identifica todas as cidades que fizeram parte da pesquisa, qual o número exato de coletas realizadas e suas porcentagens. O mapa demonstra a difusão da enfermidade por todo o estado de São Paulo.

Foram amostrados $42(8,64 \%)$ cuidadores de animais e $444(91,36 \%)$ ovinos durante os anos de 2012 a 2015 no estado de São Paulo, conforme demonstra a Fig. 2.

A prevalência de reagentes por vírusneutralização foi de $67 \%$ (IC95\%=62-71\%) nos ovinos, e em seus cuidadores de $76 \%$ (IC95\%=63-89\%), sendo $\mathrm{P}=0,22$, ou seja, não houve diferença estatística significativa entre as espécies, conforme demonstra a Tab. 1.

Neste estudo, $67,7 \%$ das amostras foram reagentes ao ORF vírus nos ovinos e 76,19\% nos cuidadores (Tab. 1). Esse resultado difere de Haig e Mercer (1998), que afirmam que a estimativa da soroprevalência da infecção pelo ORF vírus nos rebanhos é prejudicada pelo fato de o vírus induzir baixos níveis de anticorpos neutralizantes, não sendo possível a detecção em testes de soroneutralização. 


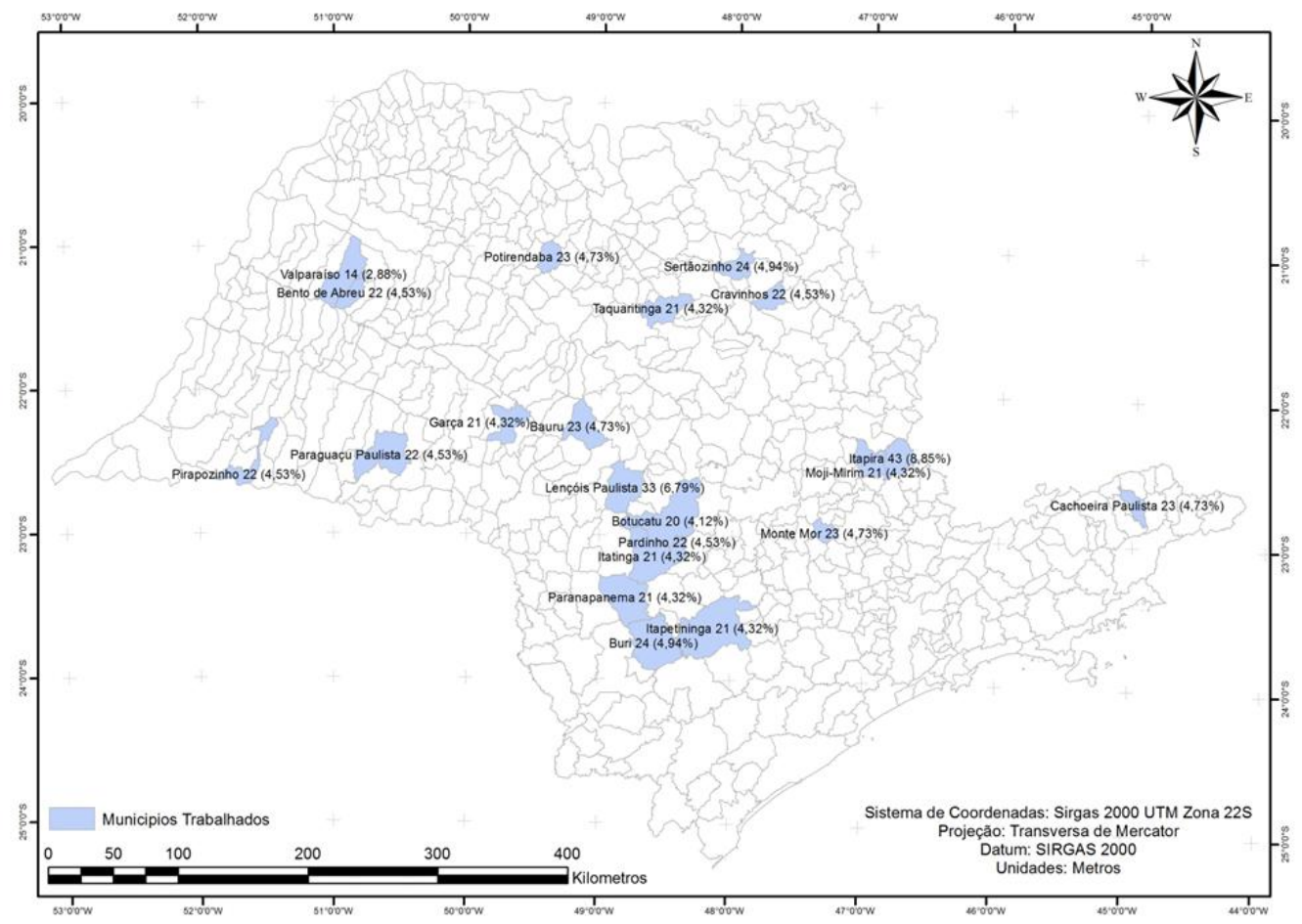

Figura 1. Distribuição e frequência das amostras coletadas por propriedade nas diferentes cidades do estado de São Paulo. Botucatu, SP- 2015.

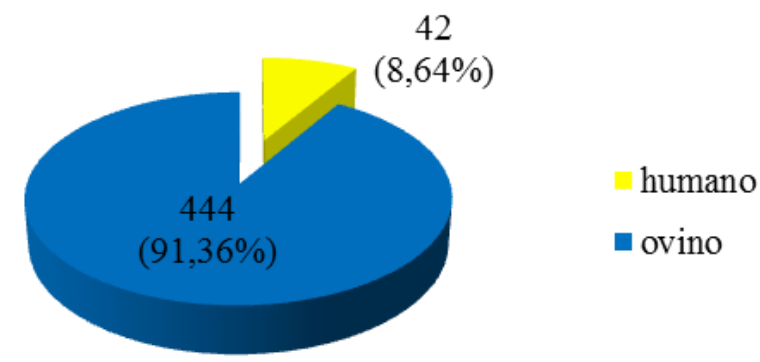

Figura 2. Frequência da coleta de amostras nas propriedades por espécie. Botucatu, SP- 2015.

Tabela 1. Prevalência do teste de vírus-neutralização no soro dos ovinos e seus cuidadores. Botucatu, SP2015

\begin{tabular}{|l|c|c|c|c|}
\hline \multicolumn{1}{c|}{ Espécie } & \multicolumn{3}{c}{ Vírus-neutralização para ectima contagioso } \\
\hline & Não reagente (NR) & Reagente* & $\begin{array}{c}\text { Índice de } \\
\text { confiança (IC) }\end{array}$ & Total \\
\hline Cuidadores dos ovinos & $10(23,81 \%)$ & $32(76,19 \%)^{\mathrm{a}}$ & $0,63-0,89$ & 42 \\
\hline Ovinos & $147(33,11 \%)$ & $297(66,89 \%)^{\mathrm{a}}$ & $0,62-0,71$ & 444 \\
\hline Total & $157(32,3 \%)$ & $329(67,7 \%)$ & & 486
\end{tabular}

*a Letras diferentes na mesma coluna indicam diferença estatística $(\mathrm{P}<0,05)$ entre as prevalências. 


\section{Ferreira et al.}

Na Fig. 3, pode-se visualizar a prevalência de anticorpos anti-ORF vírus pela técnica de vírusneutralização tanto nos ovinos quanto em seus cuidadores, quando apenas $32,3 \%$ das amostras foram não reagentes no teste. Esses resultados são diferentes daqueles de outros estudos, que afirmam que, devido ao fato de a soroprevalência nos rebanhos ser baixa, a prevalência da doença pode ser estimada com base em relatos da ocorrência da doença clínica (Robinson, 1983; Gokce et al., 2005).

A distribuição dos títulos teve diferença estatística significativa entre as espécies com $\mathrm{P}=0,0048$. As variações de titulação foram de 0,6 a 2,1, tanto nos ovinos quanto nos seus cuidadores. Essas variações estão demonstradas detalhadamente na Tab. 2 e ilustradas na Fig. 4.

$$
329
$$

$(67,70 \%)$

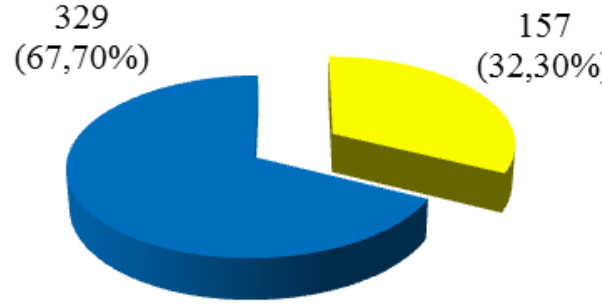

157

NR

- Reagente

Figura 3. Prevalência de anticorpos anti-ORF vírus pela técnica de vírus-neutralização em ovinos e seus cuidadores. Botucatu, SP- 2015.

Tabela 2. Distribuição dos títulos de anticorpos expressos em $\log 10$, obtidos pela vírus-neutralização no soro por espécie. Botucatu, SP- 2015

\begin{tabular}{|c|c|c|c|c|c|c|c|c|}
\hline Espécie & & & Vírus-ne & tralização pa & a ectima con & gioso & & \\
\hline $\begin{array}{l}\text { Título de } \\
\text { anticorpos* } \\
\left(\log _{10}\right)\end{array}$ & 0,6 & 0,9 & 1 & 1,2 & 1,5 & 1,8 & 2,1 & Total \\
\hline Cuidador & $1(3,13)$ & $1(3,13 \%)$ & 0 & $2(6,25 \%)$ & $1(3,13 \%)$ & $13(40,63 \%)$ & $14(43,75 \%)$ & 32 \\
\hline Ovino & $41(13,8 \%)$ & $41(13,8 \%)$ & $1(0,34 \%)$ & $35(11,78 \%)$ & $44(14,81 \%)$ & $70(23,57 \%)$ & $65(21,89 \%)$ & 297 \\
\hline Total & 42 & 42 & 1 & 37 & 45 & 83 & 79 & 329 \\
\hline
\end{tabular}

*A distribuição dos títulos foi diferente estatisticamente entre as espécies (teste de qui-quadrado, $\mathrm{P}=0,0048$ ).

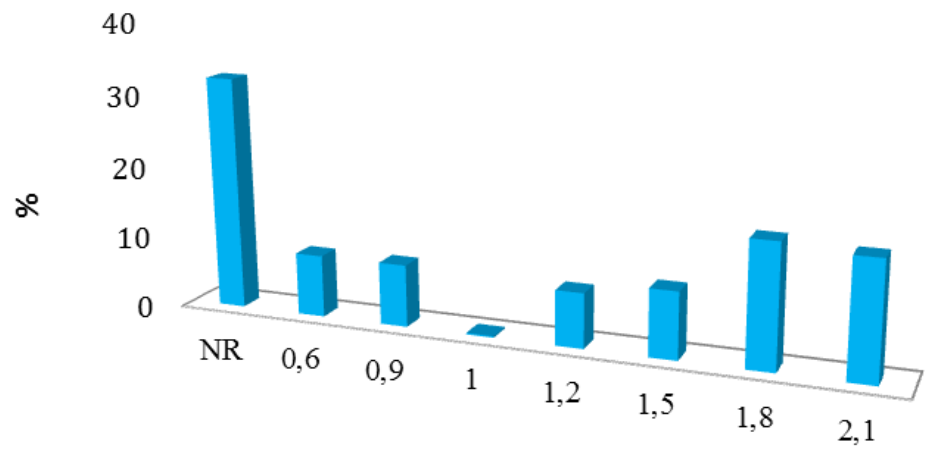

- VN Ectima

Figura 4. Distribuição dos títulos de anticorpos expressos em $\log 10$, obtidos pela vírus-neutralização no soro por espécie. Botucatu, SP- 2015.

Dentre os 42 cuidadores de ovinos participantes do estudo, 32 apresentaram títulos de anticorpos expressos por $\log 10$ acima de 0,6 . Segundo Haig e McInnes (2002), a variação dos títulos de anticorpos pode ser explicada, por exemplo, pela capacidade de o indivíduo basear sua resposta imune eficaz, ou seja, se ele já teve contato prévio, seus títulos serão mais altos, conseguindo responder à infecção viral, não deixando a doença evoluir, ou então tornando-a mais branda. 
Altos níveis na titulação de anticorpos significam que o organismo está produzindo anticorpos para combater a infecção. Dependendo do momento da coleta da amostra (pré ou pós-viremia), a concentração (título) de anticorpos poderá ser, então, influenciada. Uma titulação alta de anticorpos não significa, necessariamente, que o indivíduo já teve um contato anterior com o vírus, uma vez que, já no primeiro contato, pode ter ocorrido alta produção de anticorpos (Tizard, 2009).

A Fig. 5 ilustra como foi observado microscopicamente o controle negativo para ORF vírus em células Vero e o efeito citopático padrão (ECP) desse vírus também em células Vero.

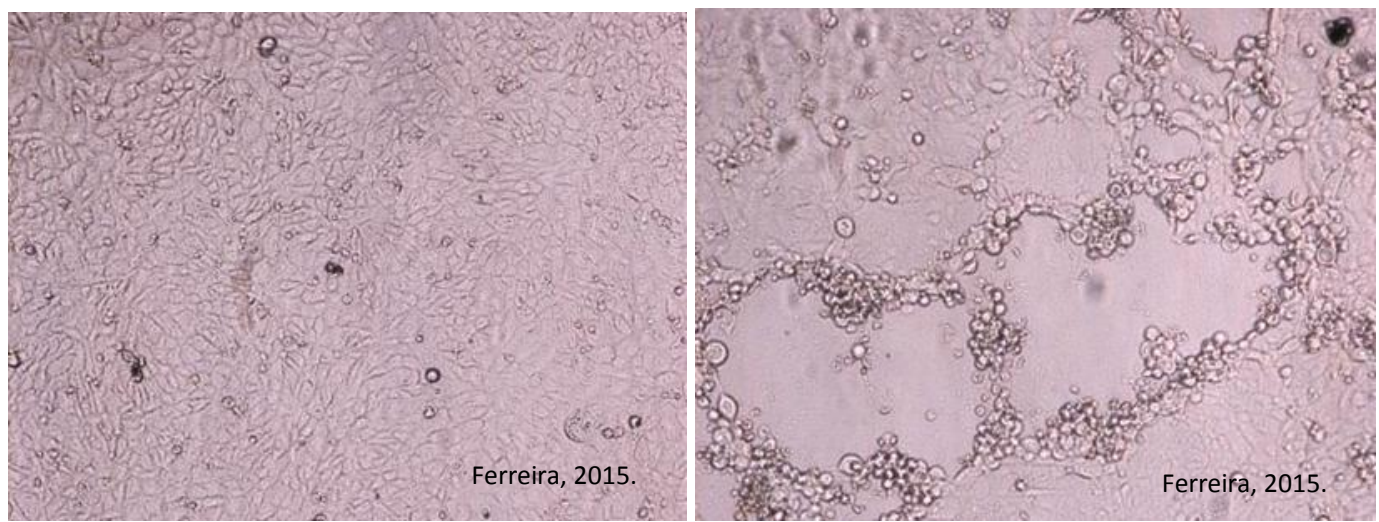

Figura 5. (A) Controle negativo - célula Vero 40x; (B) Efeito citopático padrão (ECP) - ORF vírus em células Vero 40x. Botucatu, SP- 2015.

\section{CONCLUSÕES}

Foi observada uma prevalência de soropositividade ao ORF vírus de 76,2\% entre os cuidadores dos ovinos. Estes dados sugerem que o contato dessas pessoas com ovinos infectados resulta no aumento de sua titulação.

O vírus encontra-se difundido no estado de São Paulo e essa distribuição geográfica não influenciou a sua semelhança genética.

\section{REFERÊNCIAS}

AL-SALAM, S.; NOWOTNY, N.; SOHAIL, M.R. et al. Ecthyma contagiosum (ORF)-report of a human case from the United Arab Emirates and review of the literature. J. Cutan. Pathol., v.35, p.603-607, 2008.

BARRAVIEIRA, S.R.C.S. Diseases caused by poxvirus - ORF and milker's nodules - a review. J. Venom. Anim. Toxins Incl. Trop. Dis., v.11, p.7, 2005.
BARROS, C.S.L. Ectima contagioso In: RIETCORREA, F.; SCHILD, A.L.; LEMOS, R.A.A.; BORGES, J.R. (Eds.). Doenças de ruminantes $e$ equinos. 3.ed. Santa Maria: Pallotti, 2007. p.98102.

FLEMING, S.B.; MERCER, A.A. Genus Parapoxvirus. In: MERCER, A.A.; SHMIDT, A.; WEBER, O. (Eds.). Poxviruses. Basel: Birkhäuser, 2007. p.127-165.

GEERNICK, K.; LUKITO, G.; SNOECK, R. et al. Um caso de ORF humano em paciente imunocomprometido tratadas com sucesso com creme de cidofovir. J. Med. Virol., v.64, p.543549, 2001.

GOKCE, H.I.; OKTAY, G.; GÜRBÜZ, G. Seroprevalence of contagious ecthyma in lambs and humans in Kars, Turkey. Turk. J. Vet. Anim. Sci., v.29, p.95-101, 2005.

HAIG, D.M. Orf virus infection and host immunity. Curr. Opin. Infect. Dis., v.19, p.127131, 2006.

HAIG, D.M.; McINNES, C.J. Immunity and counter-immunity during infection with the parapoxvirus Orf virus. Virus Res., v.88, p.3-16, 2002. 
HAIG, D.M.; MERCER, A.A. Ovine diseases Orf. Vet. Res., v.29, p.311-326, 1998.

KURODA, Y.; YOSHIDA, M.; SHIBAHARA, T. et al. $\mathrm{Na}$ epidemic of parapoxvirus infection among cattle: isolation and antibody survey. $J$. Vet. Med. Sci., v.61, p.749-753, 1999.

NOURANI, H.; MALEKI, M. Contagious ecthyma: case report and review. Pak. J. Biol. Sci., v.9, p.2543-2545, 2006.

PUGH, D.G. Clínica de ovinos e caprinos. São Paulo: Roca, 2005. 434p.

RADOSTITS, O.M.; GAY, C.C.; BLOOD, D.C. et al. Clínica veterinária: um tratado de doenças dos bovinos, ovinos, suínos, caprinos e equinos. 9.ed. Rio de Janeiro: Guanabara Koogan, 2012. 1770p.

REED, L.J.; MUENCH, H. A simple method of estimating fifty per cent endpoints. Am. J. Hyg., v.27, p.493-497, 1938.
ROBINSON, A.J. Prevalence of contagious pustular dermatitis (ORF) in six million lambs at slaughter: a three-years study. N. Z. Vet. J., v.31, p.161-163, 1983.

ROBINSON, A.J.; BALASSU, T.C. Contagious pustular dermatitis (ORF). Vet. Bull., v.51, p.771-782, 1981.

SAS user's guide, version 9.3. Cary: SAS, 2011.

TIZARD, I.R. Imunologia veterinária: uma introdução. 8.ed. Rio de Janeiro: Elsevier, 2009. $587 \mathrm{p}$.

UZEL, M.; SASMAZ, S.; BAKARIS, S. et al. Uma infecção viral da mão comumente observada após a festa do sacrifício: ORF humano (ORF da mão). Epidemiol. Infect., v.133, p.653-657, 2005. 